\title{
THE EFFECTIVENESS OF SELF-INDUCED UNCLASSIFIED THERAPEUTIC TREMOR FOR DECREASING SECONDARY TRAUMATIC STRESS AMONG SOCIAL WORKERS
}

\author{
Rina Eko Widarsih ${ }^{1}$, Rahma Widyana ${ }^{2}$, Siti Noor Fatmah Lailatushifah² \\ ${ }^{1}$ Puskesmas Imogiri I \\ Ngancar Karangtalun, Imogiri, Bantul, Daerah Istimewa Yogyakarta 55782 \\ ${ }^{2}$ Universitas Mercu Buana Yogyakarta \\ Jl. Raya Wates-Jogjakarta, Karanglo, Argomulyo, Kec. Sedayu, Bantul, Daerah Istimewa Yogyakarta 55752
}

1inawidarsih@gmail.com

\begin{abstract}
Secondary traumatic stress symptoms are marked by the emergence of traumatic memories experienced by other people, rejection of the stimulus that triggers traumatic memories, and emotional turmoil. If left untreated, it may lower the quality of service and health of social workers. To lower secondary traumatic stress symptoms, it is necessary to deliver psychological treatment that can be easily and independently done, is effective and costefficient, and universal. As such, Therapeutic Tremor Exercises through Self-Induction are considered appropriate to respond to this need. This study aims to identify the effect of self-induced unclassified therapeutic tremor exercises on reducing secondary traumatic stress levels. This study hypothesizes that there will be differences in secondary traumatic stress levels among social workers before and after samples are given selfinduced therapeutic tremor exercises. Subjects consisted of female social workers $(n=5)$ who were indirectly exposed to traumatic stories of victims for at least 2 hours a week. The study used a single-group pre-post design by comparing secondary trauma stress levels before and after the intervention. The intervention was a one-day joint training and 14-day independent training. Wilcoxon's signed-rank test showed significant differences with $Z=-2.023, p=.043$, whereby secondary trauma stress levels prior to the intervention $(M=45.4)$ was higher than after the intervention $(M=26.2)$.
\end{abstract}

Keywords: secondary traumatic stress, self-induced unclassified therapeutic tremor, social workers

\section{INTRODUCTION}

Research has demonstrated that helpers of trauma victims are at risk for developing post-traumatic stress disorder similar to the victim's experience due to empathic attachment (Bolic, 2019; Choi, 2011; Figley, 2002). This is termed secondary traumatic stress (STS). Secondary trauma risks individuals who work as therapists, helpers, or individuals whose professions are to assist or accompany individuals or groups of people with trauma (Branson et al., 2014), including social workers of violence cases.

Based on an initial research interview on 9 and 10 July 2019 among social workers who assist violence victims, indications of secondary traumatic stress were evident. Reexperiencing the terrible event (intrusion) from recalling a victim's experience, frequent nightmares with themes connected to assisting victims, and physiological reactions to painful symbols associated with the position as a helper were the first symptoms to emerge (nausea, fatigue, irregular menstruation, sleep disturbance, mouth ulcers). The second set of symptoms is avoidance by evading social contact (conversing) with others, avoiding conversations related to a victim's traumatic event, doing activities to escape work-related stress, and lacking interest in maintaining personal healthcare. The third set of symptoms is persistent arousal, which includes sleep disturbance (quality of sleep), becoming quickly and excessively angry, a dip in mood, impatience, impaired concentration, using high and harsh tones in answers, and hypervigilance.

The symptoms experienced by the social workers are stress reactions that, when left untreated for extended periods (over six 
months) without efforts to manage fatigue and stress, may affect physical and emotional conditions and result in poor interpersonal relations (Robinson-Keilig, 2014). Effects on physical conditions may include chronic musculoskeletal pain, hypertension, hyperlipidemia, obesity, and cardiovascular diseases (McFarlane, 2010). The ability to optimally function will also deteriorate, thus lowering self-esteem, productivity, and even turnover (Showalter, 2010). Secondary traumatic stress is also related to the lack of control over work and spending more time during leisure, which both may be responses to emerging symptoms (Kulkarni et al., 2013). When these conditions occur, the optimum quality of service and the primary purpose of victim welfare assistance may not be achieved and add to the burden of nonprofit organizations (Quinn et al., 2019). On the individual level, when STS is experienced for long periods, it is projected onto mental health deteriorations (Galek et al., 2011) and further risk reductions in quality of life (Kumar et al., 2018).

Secondary traumatic stress encompasses physical, emotional, and negative cognitive reactions that respond to indirect exposure toward trauma, such as working with trauma survivors (Gil \& Weinberg, 2015). Secondary traumatic stress symptoms are similar to post-traumatic stress disorder symptoms (PTSD; American Psychiatric Association, 2000; Canfield, 2005; Figley, 2013) and may include disturbing images or dreams related to the trauma; constant avoidance of trauma-related stimuli; and changes in core beliefs and self-beliefs (Pearlman \& Mac Ian, 1995). Collectively, these symptoms have been termed compassion fatigue (Radey \& Figley, 2007; Hannah \& Woolgar, 2018), secondary trauma (Radey \& Figley, 2007), or vicarious trauma (Craig \& Sprang, 2010; McCann \& Pearlman, 1990). Although these terms are used interchangeably in existing literature (Greinacher et al., 2019), the term secondary traumatic stress will be used throughout this article.
Working as a social worker in violence complaint agencies increases the prevalence of STS, as they are frontline personnel who fight for the right of victims (Ray et al., 2013). Social work is a profession that has roles in and functions as agents for (a) social change, (b) problem-solving in humanitarian relations, (c) empowerment and freedom, and (d) achieving welfare (Fajar \& Darwis, 2017). A social worker's responsibilities include assisting individuals and families with personal and social issues, gathering pertinent information for the client's needs and advising them on their rights and responsibilities, analyzing situations and proposing alternative solutions to problems, and compiling records or case reports for the court or other legal matters (Ministry of Manpower \& Central Bureau of Statistics, 2014).

In the context of assisting violent victims, a social worker's responsibility is to provide support, which includes assisting victims in managing PTSD symptoms, assisting victims in retelling the traumatic event, and attempting to establish a safe place and condition where feelings of helplessness, anger, and fear can be expressed (Canfield, 2005).

Secondary traumatic stress in social workers is stress resulting from their responsibilities of assisting, defending, and fighting for others who have been traumatized, exposing social workers to their clients' traumatic experiences and thus exposing them to the psychological impact of the people they help. Unlike vicarious trauma that occurs after receiving an accumulation of traumatic exposure from multiple clients over longer periods (Bolic, 2019), the trigger of STS can be short (Benuto et al., 2018). Experiencing STS, according to Figley (2013), is marked by the emergence of disturbing imagery associated with a client's memory of a traumatic event, rejection responses, psychological shock, debilitating emotions, and lowered functioning (Ariapooran \& Raziani, 2019). Declines in functioning are 
marked by lowered interpersonal relationship qualities (Senter et al., 2010), reduced work performance, and being easily involved in conflicts with other people (Figley, 2013).

Three primary STS symptoms, according to Figley (2013), include (a) reemergence of traumatic memories experienced by others through dreams or symbols related to the traumatic event (intrusion), (b) avoidance of stimuli associated with the trauma and blunted effect toward common responses (avoidance), and (c) persistent symptoms from increased arousal (that did not appear prior to trauma), marked by at least two or more symptoms of sleep difficulties or disturbance in deep restorative sleep, easily irritated or explosive anger, concentration difficulties, hypervigilance, and exaggerated startle responses (arousal).

Although the experience of STS among people may differ, the primary STS symptom is re-experiencing thoughts and dreams of traumatic events, changes in perceptions and decision making, and feelings of helplessness. Without interventions, it may lead to anhedonia, withdrawal from intimacy, depressive episodes, and an increased risk of suicide (Kulkarni et al., 2013).

Based on a review of sexes, it is argued that females have higher vulnerability than males in experiencing STS (Baum, 2015; Baum et al., 2014). Other risk factors include empathy (Wagaman et al., 2015; Zaki \& Ochsner, 2012; Gibbons, 2011), the degree of exposure to traumatic cases (MacRitchie \& Leibowitz, 2010), the intensity of case assistance or intensity of exposure (Hensel et al., 2015), the interactive experiences with traumatic cases (Figley, 2012), and a history of trauma from being a helper/social worker (Hensel et al., 2015; Gil \& Weinber, 2015; Jenkins et al., 2010). There are also factors of emotional fatigue, lack of social support, and use of cigarettes and alcohol (Greinacher et al., 2019).

Aside from risk factors, there are also protective factors that speed recovery from STS. Such factors include awareness toward emotional management (Wagaman et al., 2015), good formal social support through therapy and professional supervision (Gil \& Weinber, 2015), or informal support through supervision from intra-division colleagues, and support from family, friends, and the community (MacRitchie \& Leibowitz, 2010), coping strategies in dealing with problems, and internal strengths (Gil \& Weinberg, 2015).

From a neurological standpoint, the phenomenon of stress and trauma is understood as a disturbance in stress processing. When stress occurs, there are reductions in the ability interplays with the brain's information processing system, covering the neocortex's sensory regions, brainstem, basal ganglia, thalamus, and limbic system. (Herold, 2015). The psychophysical system (autonomic nervous system, sympathetic and parasympathetic) and the neurohormonal system (activation of the hypothalamic-pituitary-adrenal axis) become active as a defense mechanism during a traumatic incident (HPA). Trauma situations can elicit a fight, flight, or freeze (immobility) reaction pattern, or in other words, a fight or flight response (hyperarousal) triggered by psychological system activation (autonomic nerve system) and neurohormonal system activation (Senior, 2017). Stress and stress vulnerability can thus be widely defined as inadequacies to balance the autonomic nervous system and parasympathetic nervous system while in a resting state (Mazon et al., 2018).

Key role in emotion is played by the central nervous system, this has been proven in studies of the correlation between the brain and emotions in neuroscience studies. It was further explained that emotions involve two brain areas: the cortices (frontal, temporal, and parietal) and subcortical regions of the limbic system covering the basal ganglia, thalamus, amygdala, and hippocampus (Levenson, 2014). In typical situations, the brain retrieves information, processes it through emotions within the limbic system 
and sends it to the neocortex for analysis, logic, and considered responses. Whereas in traumatic states, the brain pressures the first areas (brainstem and limbic system) because it is required to act quickly and instinctively. This process is termed Action/Reaction, aimed at protecting oneself from danger. When living in repeated or long-term danger, the mindset will be reinforced. The more often the mindset is used, the brain becomes accustomed to the mindset, although no longer in dangerous situations. Eventually, even the slightest pressures activate the action/reaction neural network, and an individual starts to live a life under the function of traumatic neurology (Berceli, 2017).

Based on the Polyvagal Theory proposed by Stephen W. Porges, chronic stress and trauma cause an individual to suffer from a dysfunctional imbalance response between the parasympathetic and sympathetic nervous systems (Porges, 2012). The mechanism and order of action of the three autonomous nervous systems are similar to a ladder, with the highest step being (1) the ventral vagus, which is active under secure situations, followed by (2) the sympathetic nervous system, which is active when under danger, and the lowest being (3) the dorsal vagus, which is active when under extreme danger (Porges, 2012).

Post-traumatic stress disorder, when viewed from the Polyvagus Theory, has two explanations. Firstly, chronic post-traumatic conditions occur when the sympathetic nervous system activates and produces a fight, flight, or freeze response. Secondly, chronic post-traumatic conditions occur when the dorsal vagus activates and stimulates a withdrawal or isolation response due to fear, helplessness, and desperation (Porges, 2012). In addition, the neurohormonal system is also activated (Senior, 2014), which triggers the production of stress hormones.

According to the Polyvagus Theory, various information that originates from within the body, environments, or other individuals, are given meaning from the autonomous nervous system's extremely rapid processing (Klarer et al., 2014), termed neuroception (Porges, 2012). Intentions produced through this process can either be one of the following: safe, unsafe/dangerous, or life-threatening. Following this process, the nervous system begins and yields responses according to each meaning (Porges, 2012). The mechanism of neuroceptions is based on a habitual pattern of life experiences, whether positive and empowering or even traumatic (Dana, 2018). When neuroceptions function well, it is a mechanism that maintains individual safety and wellbeing. However, neuroceptions may also be erroneous due to past trauma, various internal negative emotions, the influence of drugs, physical fatigue, low blood sugar, illness, or even when an individual is in love (Levenson, 2014).

When stimuli are deemed dangerous (either by the physical self or the social self), the hypothalamic-pituitary-adrenal axis (HPA) is instinctively activated (Berceli, 2010). Activation of the HPA instigates activation of the adrenal gland by increasing the production of adrenaline and cortisol to prepare for a fight/flight response (Berceli, 2017). Arousal is conveyed from the psychophysical system to the somato motor system in the fight/flight response (Berceli, 2010). For self-defence, the skeletal muscles contract to curl into a fetal position (flexor withdrawal) (Berceli, 2017). This reflex-type contraction is commanded by the psoas muscles (Koch, 2019), along with the diaphragm that plays a role in sending messages to and from the visceral brain concerning safe/dangerous situations (Mazon et al., 2018). When the danger has subsided, the vigilance mode is ideally inactive. Yet, due to repeated stress-response factors and the inability to complete the process, the sympathetic nervous system is constantly activated for extended periods (Senior, 2014), and the HPA is yet able to deactivate completely (Berceli, 2010). This condition 
causes neuroception to misinterpret information frequently; neutral or nonproblematic information is frequently misinterpreted as frightening or hazardous. This obstructs the emergence of sensations of peace, security, joy, activity, attention, excitement, and life enjoyment, all of which can be realized when the ventral vagus nerve system is engaged (Porges, 2012). Therefore, interventions to lower stress and trauma are needed to activate the parasympathetic nervous system and deactivate the HPA axis.

Efforts to reduce STS symptoms through psychological interventions have been done, whether on the organizational or on the individual level. On the organizational level, interventions are part of an organizational structure in an institution (Lee, 2017), such as through adequate supervision, workshops, and efforts to establish an organizational culture that supports the mental health maintenance of the organization's staff.

Psychological approaches used at the individual level include cognitive approaches, psychodynamic approaches, gestalt, combination methods, mindfulness, and body-based intervention methods. The cognitive approach includes cognitive procedures (Horowitz, 2011), which includes the compassion fatigue resilience (CFR) model (Ludick \& Figley, 2017; Shew, 2010). Psychodynamic approaches and imaginative procedures, for example, are Psychodynamic Imaginative Trauma Therapy (PITT) (Maack, 2012). Gestalt-based treatment is dialogical exposure (Butollo, et al., 2014). The combination methods include Eye Movement Desensitization and Reprocessing or EMDR (Shapiro \& Forrest, 2016), brainspotting (Brainspotting, 2019), Bonny Method of Guided Imagery and Music (GIM) and its Adaptations (Maack, 2012), and music therapy (Wlodarczyk, 2010). Other techniques are therapy with resource-oriented procedures (Priebe, Omer, Giacco, \& Slade, 2014), sensory motor therapy (Gene-Cos, et al., 2016; Fisher \& Ogden, 2013), mindfulness-based intervention procedures (Follette, et al., 2015) and body-based intervention procedures. Intervention procedures that are based on the body include somatic experiencing (Brom et al., 2017), yoga (Descilo et al., 2010; Kolk et al., 2014; Price et al., 2017; Spinazzola et al., 2011; West et al., 2017), reiki (Novoa \& Cain, 2014), and Self-Induced Therapeutic Tremors (Berceli et al., 2014). The interventions can be done individually or in groups, yet techniques that can be done independently as a self-care method are still minimal. Self-care techniques are thus recommended by Quinn et al. (2019) as it can be administered separately, and are flexible in terms of time, place, and costefficiency.

Personally, social workers are advised to maintain self-care to reduce the risk of STS (Quinn et al., 2019) and enhance resilience (Johansen et al., 2019). One technique that can be categorized as self-administered selfcare is Self-Induced Unclassified Therapeutic Tremors (SUTT). Essentially, SUTT releases tension through muscular vibrations that occur automatically and naturally (Berceli, 2017). SUTT exercises, which are physical practices, will deactivate the HPA and thus trigger natural bodily tremors. The parasympathetic nervous system will take over after the HPA is deactivated, allowing the individual to return to a relaxed state and reducing secondary traumatic stress reactions.The parasympathetic nervous system will take over after the HPA is deactivated, allowing the individual to return to a relaxed state and reducing secondary traumatic stress reactions. Activation of tremors that naturally occur will disturb the remaining tension and chemical residue in the autonomous nervous system throughout the secondary traumatic stress condition. The tremors will signal the brain that danger has subsided, and the brain must shut down its alert state (Berceli, 2017). The therapeutic influence of physical exercises is based on the principle that "experience shapes the brain" (Kolb \& Gibb, 2014; Lövdén et al., 
2013). Millions of individual interactive experiences are termed metaplasticity, whereby cerebral structure changes are associated with an individual's learning process (Kolb \& Gibb, 2014).

SUTT was chosen as the study's intervention because of its ease of use and direct benefits in reducing hyperarousal and muscular tension (Heath \& Beattie, 2019), as well as the fact that it does not require participants to share their problems, as is the case with most psychological interventions for STS. In line with this, sharing problem is known as talking cure or talk therapy has several challenges, mainly due to culture. In nonwestern societies, discussing psychological stress symptoms outside the family or group is taboo, making talk therapy less effective (Hardy et al., 2018). Stigmatization, such as stereotyping, discrimination, and other discriminatory views held by the community, may also impede its effectiveness. (Ciftci et al., 2013). Other issues in talk therapy may include the need for insight to plan follow-up strategies, whereby insight may impede the subcortical intuitive process, which pressures emotions and physiological sensations (Wilkinson, 2003) when necessary to release stress and trauma. Furthermore, trauma has substantial cultural dimensions and complex issues in human psychopathology, making interventions with cognitive approaches less valid in non-western cultures and middleincome societies. Bodily-based therapies targeting limbic subcortical neurophysiological processes are a way that can be universally accepted and appropriate for culturally different groups (Herold, 2015), such as what occurs during SUTT.

Operationally, SUTT consists of seven stretching exercises that trigger neurogenic tremors (Herold, 2015). SUTT begins with physical training that triggers and increases the central nervous system's activity. It positively affects brain functioning and affective-cognitive performance by involving neurotropic, neuroendocrine, neuropeptide, and neurotransmitter systems. This mechanism occurs as aspects of executive function are directly related to physical activity (Loprinzi et al., 2020). Exercise training enhances brain plasticity by boosting neurogenerative, neuroadaptive, and neuroprotective processes, according to neurobiological studies on the subject. (Dishman et al., 2012).

Unfortunately, no single treatment is substantiated as most effective in reducing STS symptoms (Bercier \& Maynard, 2015). Meanwhile, it is essential to provide effective interventions to help reduce secondary traumatic stress symptoms that can be done independently. Therefore, it is necessary to test the effectiveness of SUTT's approach in reducing STS symptoms.

This study hypothesizes that therapeutic tremor exercises through self-induction may lower secondary traumatic stress levels; specifically, secondary traumatic stress levels in social works would be lower after they are given SUTT exercises than the stress levels before SUTT training. This study aims to determine the effectiveness of SUTT training in lowering STS symptoms in social workers. If this study can be substantiated, then SUTT training can be recommended as an alternative intervention to reduce secondary traumatic stress symptoms experienced by social workers.

\section{METHOD}

\section{Participants}

Participants were required to meet the following criteria:

1. Female. This criterion is based on the evidence that demonstrates how females have greater vulnerability to STS than males (Baum, 2015).

2. Spends a minimum of 2 hours per week being exposed to victims' experiences of violence. This criterion points to the workload of case assistance in social workers, whereby each day is spent with at least one counselling activity that lasts 2 hours on average per case (Annisa, 2018). 
3. The social worker is not receiving any other intervention or psychotherapy.

4. The social worker is willing to participate in the intervention for 14 days, verified by completing an informed consent sheet.

5. Has moderate to severe STS levels based on score of the STS scale.

The authors published an open recruitment notice to social workers who worked at organization X. Organization X is a women's crisis center (WCC X). The organization was selected as it provides special services specifically for the defense of violence victims; hence social workers' risk is higher in experiencing STS.

Publication and participant recruitment were held throughout 19-26 December 2019, whereby seven interested individuals enrolled and then completed the STS scale for screening. Of the seven participants, six met the criteria as research participants. Of the six, one dropped out as the participant only practiced for nine days due to labor, considered mortality. Five participants completed the entire intervention procedure (pretest, joint training, 14-day independent training, post-test, and follow-up). Participants' age range was 34-45 years $(M=36.8 ; \quad S D=13.1), \quad$ with the latest education level being undergraduate andpost graduate level of education. The duration of work as a social worker ranged from 2-8 years.

\section{Study procedures}

The study applied a one-group pre-post design (Jackson, 2015). The authors had difficulty finding an organization that matched the characteristics of WCC X as a control group in the same region accessible to the authors, considering multiple resource limitations. Because of this, the study design used a one-group pre-post design. Studies that apply one-group pre-post designs with only five subjects have previously been done by Landis (2010) in a study that recruited marriage therapists who received expressive arts-integrated workshops to reduce the STS risk. Another study by Suparti (2014) also used only five subjects and one other by Halida et al. (2016) with six subjects, and both were action-based studies.

The authors controlled for outstanding variables by controlling the fidelity for participant criteria. The intervention's lengthy duration was also a challenge to this study; hence the authors optimized the group dynamics' function as part of the intervention. One of the participants made a WhatsApp group and communicated with participants throughout the intervention process.

The intervention administered was: one joint training session and 14-day independent training. The study applied a 14-day intervention based on Berceli's (2009) study that implemented SUTT training toward university students to lower stress.

The SUTT module was arranged with reference to the steps suggested by Herold (2015) and Berceli (2017), encompassing seven stretching exercises to trigger neurogenic tremors and integration. The authors made additions to the Introduction Session, Introduction to Materials Session, and Integration Session. After this arrangement, the module went through a professional judgment process, judged by Martaria Rizqy Rinaldi, S.Psi., M.Psi., Psikolog, a lecturer at Mercu Buana University Yogyakarta's Faculty of Psychology. The following input was given; (1) the language to be used should be adjusted to respondents' education level, (2) the facilitation should deliver alternative statements in all sessions to achieve the session's objectives, and (3) steps and stages in all sessions should be more operationalized. The authors revised the module based on the input above, conducted try-outs, and made additional revisions before implementation to the research participants.

Following this, informed consent and baseline data were obtained on 2-3 January 
2020. SUTT joint training was conducted on 13 January 2020 with the trainer. In this joint training, subjects received SUTT's theoretical bases (60 minutes) and practice (120 minutes). After joint training, participants implemented independent training from 13-26 January 2020 (14 days) with a 15-minute maximum duration each day. The total independent training duration was 3.5 hours. Prior to independent training, subjects were informed of SUTT's technical administration. Following independent training, post-tests were administered on 28 January 2020, and follow-up data were collected seven days after this, 4-6 February 2020.

\section{Measurements}

The data collection instrument was the STS Scale and personal journals in rating scales that participants filled independently as selfreports. Other than this, semi-structured interviews were done before and after the intervention. This interview was aimed at descriptively corroborating the scale measure's results.

The STS scale was formulated by Bride et al. (2004), which measures the frequency of three STS dimensions: avoidance, intrusion, and altruism, as explained through 17 items. The STS' overall reliability testing results were $(\alpha=.93)$, intrusion $(\alpha=.80)$, avoidance $(\alpha=.87)$, and arousal $(\alpha=.83)$. The authors used the scales by Bride after adaptations by Ramadhan (2016) into Indonesian (Bahasa Indonesia) with scale reliability after the adaptation at $\alpha=.933$. The STS scale is categorized as a written self-report, instructed to be filled according to the subject's condition over the past seven days. Responses were rated on a Likert scale ranging from 1 (never) to 5 (very often). Total scores and subscale scores were generated by adding the scores in each item. The higher the scores, indicate greater the STS levels. The STS scale was administered three times: before joint training, post-test, and follow-up. Data were analyzed using
Wilcoxon's Signed Ranks Test to test for STS score differences before and after the intervention on the same subject.

Supplementary data sources to identify changes were personal journals in the form of a self-reported rating scale. Participants used these private journals to track daily changes. The rating scale form is comprised of 20 items that indicate STS symptoms. Ratings ranged from one (low-quality emergence) to ten (high-quality emergence). Subjects provided daily reports by circling the most appropriate rating according to their conditions. At the end of the question list, the authors provided an empty section for the subjects to provide more detailed descriptions if they wished to do so.

Interview data was also a supplementary source and was conducted at baseline and follow-up. The semi-structured interview was aimed to obtain in-depth information on participants' experiences related to STS aspects, in which these aspects also served as the interview guide. The author wrote down the participants' responses as the interview did not use recording or video devices to consider the participants' comfort.

\section{RESULT AND DISCUSSION}

The study participants' demographic data were displayed in Table 1.

Table 1.

Participant Demographics

\begin{tabular}{cccc}
\hline Initial & Age & Education & Tenure \\
\hline I & 34 & Bachelor's & 8 years \\
L & 24 & Bachelor's & 2 years \\
A & 26 & Master's & 4 years \\
H & 55 & Bachelor's & 7 years \\
N & 45 & Masters & 5 years \\
\hline
\end{tabular}

Hypothesis testing used Wilcoxon Signed Ranks Test to test for Secondary Traumatic Stress differences before and after the intervention. Test results were displayed in Table 2. 
Table 2.

Paired Difference Test Results

\begin{tabular}{ccc}
\hline & $\begin{array}{c}\text { Post-test } \\
\text { Pretest }\end{array}$ & $\begin{array}{c}\text { Follow up test - } \\
\text { Post-test }\end{array}$ \\
\hline$Z$ & -2.023 & -1.342 \\
$p$ & $.043^{*}$ & .180 \\
${ }^{*} p<.05$ & &
\end{tabular}

The data met the assumption requirements that included normality and homogeneity testing. Based on the analysis above, $\mathrm{KE} Z=$ $-2.023, p=.043$ was generated, meaning that significant differences in secondary traumatic stress levels were shown before and after the 14-day SUTT training was administered, whereby secondary traumatic stress levels after SUTT training were lower than before SUTT training.

The results support Lynning et al. (2012) and Heath and Beattie's (2019) findings demonstrating how SUTT exercise lowers stress levels. Self-induced Therapeutic Tremor was a therapeutic approach through integrated neurophysiological tremors to achieve homeostasis from stress conditions (Berceli, 2010; 2017).

Tremors activated and occurred naturally will shake off the chemical residue and remaining tension throughout the traumatic period. Tremors would protract the muscles so that the brain is recognized that the conditions were safe (Herold, 2015) and shut down its alarm system (Berceli, 2017). In people with Restless Legs Syndrome, SUTT training can lower the severity of sensorimotor disorders as marked by the unpleasant urge to move legs (Harrison et al., 2018).

\section{Table 3.}

Descriptive Statistics of Subjects' Scores

\begin{tabular}{lccc}
\multicolumn{1}{c}{ Test } & Min & Max & Mean $(S D)$ \\
\hline Pretest & 36 & 56 & $45.4(8.65)$ \\
Posttest & 18 & 41 & $26.2(9.36)$ \\
Follow up test & 18 & 29 & $22.8(5.67)$ \\
\hline
\end{tabular}

Pre-post-follow-up measurement results were shown in Table 3. The above post- and follow-up test results augment the 14-day intervention's ability to work optimally for the study participants throughout the intervention process.

There were also reductions in the average level of secondary traumatic stress from preto post-test and from post-test to follow-up. Comparisons were presented in the Figure 1.

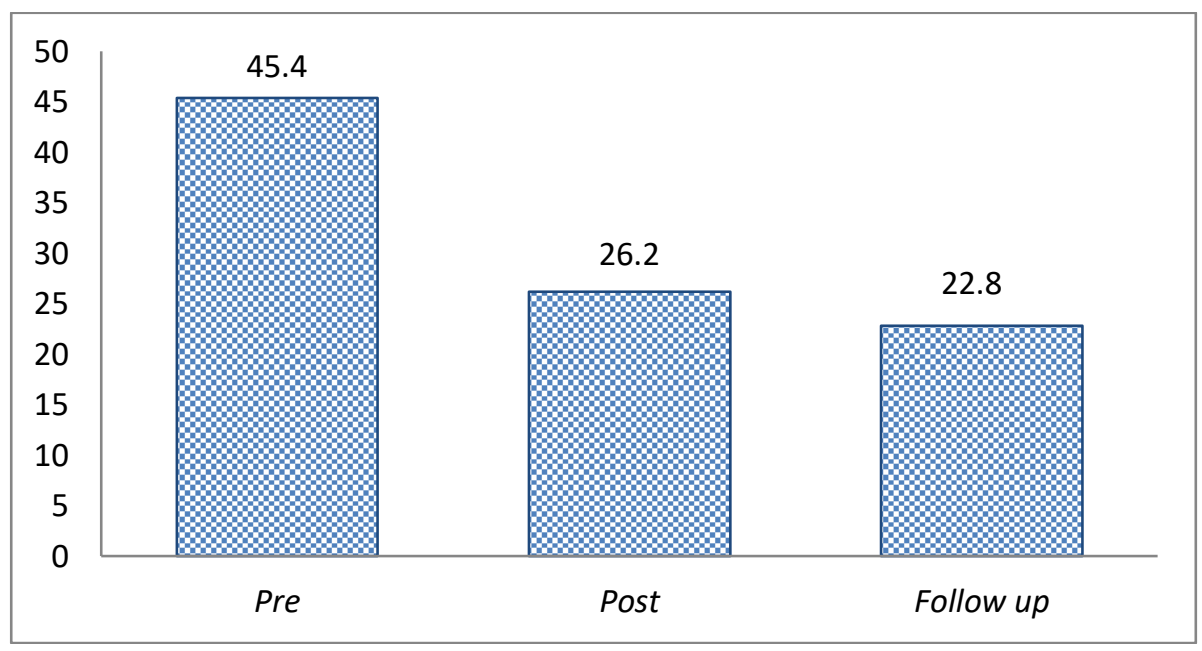

Figure 1. Changes in the Mean Levels of Secondary Traumatic Stress at Pre-Post-Follow Up Points

When the STS dimensions' mean scores were compared, results showed that all three dimensions (avoidance, intrusion, and arousal) appeared to decrease. This interdimensional mean score comparison was presented in Figure 2. 
Based on the diagram in Figure 2, results avoidance dimension at 8 points, followed by showed that the most significant gain score intrusion at 6.6 points, and the last arousal at reduction (Pretest - Posttest) was in the 4.6 points.

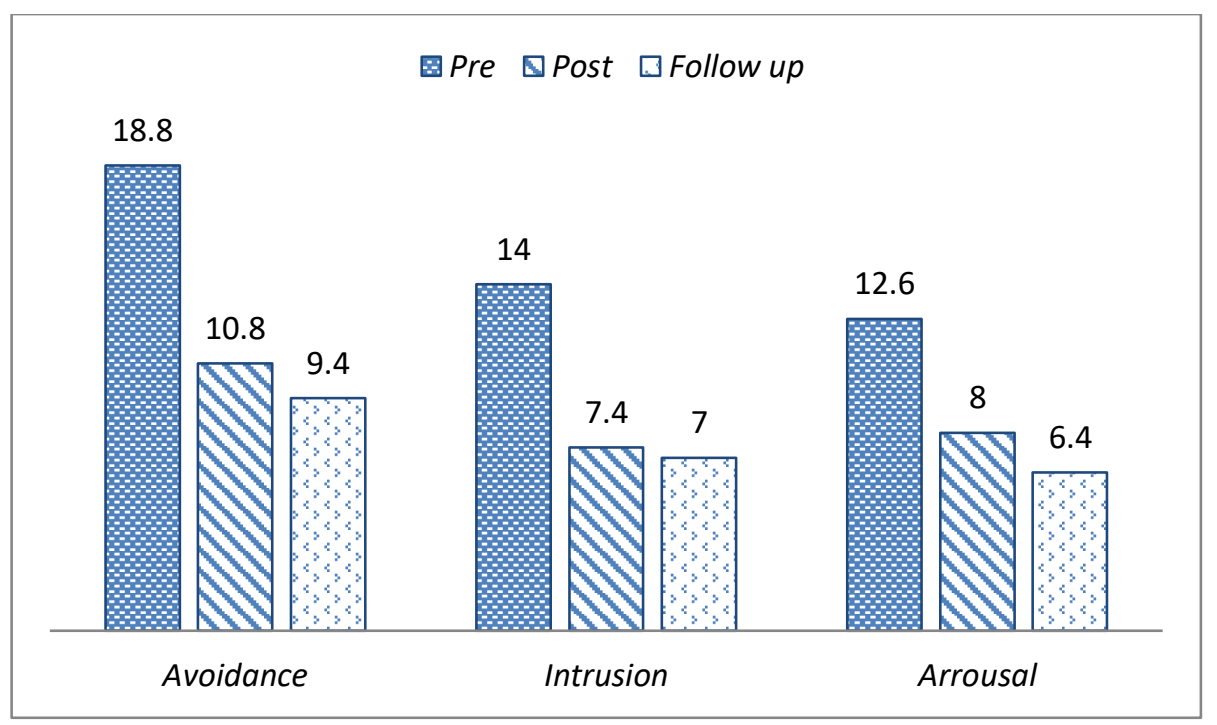

Figure 2. Comparisons of STS' Inter-Dimensional Mean Scores at Pre-Post-Follow Up Points

A new finding in this study was considerable STS symptom reduction in the avoidance dimension. Based on this finding, it can be asserted that subjects experienced an increased awareness of themselves within the cognitive, emotional, behavior, and roles.

A reduction in the avoidance dimension was corroborated by the experience of subject A, who showed an increased ability to feel the affect. This increase began with enhancements in subject A's ability to become entirely aware of the body, as elaborated in the interview excerpt below.

"Aku tuh merasa bingung, memangnya bahagia itu bagaimana sih, biasa-biasa saja menurutku, di saat orang lain (menurut mereka) merasa senang. Pas latihan, aku pernah merasakan gemetaran di area bibir, serasa seperti ketarik-tarik ke atas gitu. Sekarang aku merasa perasaanku lega. Aku mulai bisa mengatakan kepada diriku, okey kujalani, kulalui"

["I feel confused about how happiness is supposed to feel. I feel like it is normal when other people (according to them) feel happy. During training, I once felt my lips quiver, like it was pulled upwards. Now I feel relieved. I feel like I can tell myself, ok, I will do this, I will pass this".]

Table 3.

STS Pre- and Posttest Dimensional Scores

\begin{tabular}{ccccccccccc}
\hline \multirow{2}{*}{ No. } & \multirow{2}{*}{ Subject } & \multicolumn{4}{c}{ Avoidance } & \multicolumn{4}{c}{ Intrusion } & \multicolumn{3}{c}{ Arousal } \\
\cline { 2 - 11 } & & Pre & Post & Desc. & Pre & Post & Desc. & Pre & Post & Desc. \\
\hline 1. & I & 17 & 8 & Reduced & 16 & 5 & Reduced & 9 & 5 & Reduced \\
2. & L & 21 & 8 & Reduced & 18 & 9 & Reduced & 17 & 7 & Reduced \\
3. & A & 23 & 19 & Reduced & 14 & 10 & Reduced & 16 & 12 & Reduced \\
4. & N & 17 & 7 & Reduced & 10 & 5 & Reduced & 9 & 7 & Reduced \\
5. & H & 16 & 12 & Reduced & 12 & 8 & Reduced & 12 & 9 & Reduced \\
\hline
\end{tabular}

Based on Table 3 above, all STS levels were reduced in all three dimensions, whether in avoidance, intrusion, and arousal, as shown by all subjects. Following this, Wilcoxon- 
tests were done toward STS levels from before and after the intervention for all dimensions. The test results are shown in Table 4.

\section{Table 4.}

Wilcoxon-tests for Pre- and Post-test Scores in Each Dimension

\begin{tabular}{cccc}
\hline & Avoidance & Intrusion & Arousal \\
\hline$Z$ & -2.032 & -2.032 & -2.032 \\
$p$ & $.042^{*}$ & $.042^{*}$ & $.042^{*}$ \\
${ }^{*} p<.05$ & & &
\end{tabular}

From the statistical tests above, significant differences were found between pre-and post-test scores for all three dimensions (avoidance, intrusion, and arousal) with $Z=$ $2.032(p<.05)$. It can be said that the contribution of changes was equal from all dimensions, whether in avoidance, intrusion, or arousal. Similarly, there was a general illustration of each subject's score changes toward each STS indicator on a day-to-day basis throughout the 14-day intervention. The reports from the participants' journals showed that all subjects experienced reductions in STS symptoms on all three dimensions (intrusion, avoidance, and arousal).

As stated in the excerpt below, STS symptom reduction in intrusion is marked by a significant decrease in dreaming about subject L's assisted victim. This finding supports Lynning's study, whereby SUTT training successfully lowered stress levels in patients with multiple sclerosis as marked by reductions in fatigue and an increase in sleep quality (Lynning et al., 2001).

"Aku sekarang mimpi isi tema ringan, bukan pekerjaan. Dulu sering mimpi buruk, dikejar-kejar, mimpi klien. Bahkan pas hari ke-7 latihan, malamnya tidurku sama sekali tidak bermimpi. Bangun rasanya seger banget, bahagiaaa rasanya. Ternyata tidur nggak mimpi itu enak ya”.
["I now have lightly-themed dreams, not about work. I used to have nightmares, being chased after, the client's dreams. Even on the $7^{\text {th }}$ training day, at night, I had a dreamless sleep. I felt very refreshed when I woke up, I was delighted. Turns out having a dreamless sleep is nice."]

In all subject's journals, regulations in thoughts and emotions were also generally shown, as stated by subject $\mathrm{L}$ in the following excerpt. This testimony supports the theory that an organized mind, in turn, will enhance emotion and thought regulation (Price \& Hooven, 2018). An organized body will then enhance stress management abilities and wellbeing (Heath \& Beattie, 2019).
"Dulu, aku lebih mudah tersulut jika ada stimulus, sekarang tidak. Aku sekarang lebih mudah ambil keputusan, rasanya setelah stres sudah rilis secara fisik, bikin jernih pikiran".
["Back then, I was more easily triggered by stimuli, now I am not. It is easier for me to make decisions now. It feels like when stress is physically released, it clears the mind."]

From the interview excerpt above, what the subject experienced is an example of reductions in intrusion as marked by decreased intensity of the emergence of a clients' traumatic memory, no longer dreaming about clients, and reductions in stress levels when exposed to symbols that trigger client-related memories.

In some subjects, increases in STS symptoms still occurred while the intervention was in progress. Increasing of STS symptoms may be since the subjects still worked throughout the intervention process, whereby they were still exposed to the violent victim's traumatic accounts. Nonetheless, the STS symptoms tended to decline at the end of the intervention and even continued to fall before follow-up. 
Responses on feeling physically comfortable were stated by participants at the end of the first training session, which was the joint training. During this joint training's integration process, there was a participant who smiled and stated, "my body feels fresh. I feel lighter." Another similar statement was, "my body feels lighter, and I wonder why I feel sleepy." The condition that subjects feel supports the theory on the effects that occur when the HPA is deactivated. A non-active HPA causes the parasympathetic nervous system, marked by a normal heart rate, calmness, and slow breathing. This condition will result in comfort and relaxation/drowsiness (Porges, 2012). Neurophysiological tremors that appear are beneficial in loosening muscles that previously contracted from stress (Herold, 2015) and serve to release contained energy in the autonomous nervous system (Berceli, 2017).

Based on the statistical analysis on STS' mean score reductions from post-test to follow-up, subjects showed positive changes at follow-up. In the follow-up interview, subjects N, I, and $\mathrm{H}$ reported feeling emotionally calmer in the past week. Subject $\mathrm{N}$ reported the changes she experienced when recalling the victim she assisted, as elaborated in the excerpt below.

“...tidak sekhawatir dulu. Aku sekarang agak loss, tidak mikir banget-banget. Kalau dulu aku ikut memikirkan, lalu ada rasa bersalah kenapa kemarin aku nggak bilang mengenai informasi itu ya, lalu pengen buru-buru hubungi klien. Dulu jadi kepikiran. Sekarang aku tahu, kapan aku mikir kapan aku istirahat. Aku sudah bisa bilang pada diriku, aku butuh istirahat. Yang penting kita sudah usahakan, bantu. Jika memang tidak sesuai yo nggak usah dipikir-pikir terus". ["... not as worried as before. I now feel loose, not overthinking things. Before I would overthink things and feel guilty if I did not provide certain information the day before, then I would immediately contact the client. I would repeatedly think about it. Now I know when I should think of things and when to rest. I can tell myself; I need a break. The main thing is, we did our best to help. If it isn't done accordingly, then we don't need to overthink it."]

Subject I experienced changes in her response toward the stimuli at home that were potential anger triggers. The following is subject I's statement.

"Apabila ingat kerjaan atau kejadian yang dialami klien, dulu aku sebel kebawa sampai rumah. Sekarang aku relatif stabil. Indikatornya adalah relasiku dengan suami. Biasanya yang terjadi adalah, dia salah dikit saja aku sudah sebel banget, sekarang load kerja semakin tinggi, aku biasa aja. Sekarang tuh rasanya sampai rumah capek namun fisik saja".

["When I think about work or a client's incidents, I would be irritated until I get home. Now I am relatively stable. The indicator is my relationship with my husband. What would usually happen is, if he makes minor mistakes, I would be very annoyed. Now that my workload is higher, I feel normal about it. Now when I arrive home, I would feel tired but only physically tired."]

Emotional stability experienced by subject I after doing the SUTT exercise,supports Price and Hooven's (2018) statement that a physically exhausted body due to work has made participants realize that this type of exhaustion does not overpower their emotions. Price and Hooven's explanation also concur with subject H's experience in realizing positive changes after the 14-day SUTT training followed by independent exercise.

"Setelah latihan terasa loss, tubuh rileks sehingga aku menyempatkan latihan TTID jika malam. Latihan ini sederhana, enak dilakukan, enak di tubuh. Aku menyempatkan karena habis latihan plong 
pikiran, terasa segar sehingga aku lebih siap memikirkan hal-hal lain".

["After the training, I feel loose, my body is relaxed, and I make time to practice SUTT at night. It is a simple exercise, nice to do, and good for the body. I make time for it because, after this exercise, my mind is clearer, refreshed, so I am more prepared to think of other things."]

Subject A reported changes that she felt when dealing with victims with changing needs, as described below.

"Dulu aku suka kesel kalo begini, korban pengen cerai, sudah kubuatkan berkasberkasnya ehh malah berubah nggak jadi cerai. Atau begini, proses pendampingan tidak sesuai dengan harapanku, harusnya udah ada perkembangan dari kepolisian namun kok belum. Dulu aku suka ngeluh di grup, kok begini. Sekarang tak loske wae. Kalau memang keputusan berubah, bagaimana lagi. Aku memilih menjelaskan konsekuensinya di awal agar klien mengerti. Lalu tugasku membantu saja, keputusan kembali padanya, aku hormati. Dulu aku ingin langsung menelpon, menanyakan perkembangan kasus. Sekarang aku cenderung menyurati instansi, bukan telpon untuk komunikasi. Aku setel kendho".

["I used to feel annoyed when it is like this, the victim wants a divorce, I've prepared the files then they decide not to divorce. The assistance process doesn't meet my expectations of the police's progress, but nothing is progressing. I used to complain in the group, why it is like this. Now I just let it go. If a decision changes, what can be done? I prefer explaining the consequences from the start, so clients understand. Then my job is to assist merely, and the decision is theirs. I respect that. Previously I would prefer to contact them immediately, ask about the case development. Now I tend to just report to the institution, not call to communicate. I set it to be relaxed."]
By examining subject, A and I's experiences who report changes in their emotional instability, which is a dimension of arousal, this may be due to neurogenic tremor's mechanism of action. The tremor's mechanism reduces or impedes the amygdala's activation, making the neural network with traumatic loads gradually deleted in procedural memory. Neurogenic tremors can delete negative neural networks and shape positive neural networks (Senior, 2017). Then, the tremor produces subjective effects as triggered by the SUTT exercise that is mostly feelings of tranquility and relaxation, reductions in emotional instability, an increase in body image, and enhanced tolerance (Herold, 2015).

As described below, reductions in the avoidance dimension were also shown in some subjects, such as subject L.

"Aku sekarang nggak kepikiran lagi
tentang klien. Sekarang yowis ngalir,
nggak hindari kasus yang sudah
kuprediksi bakal lama selesainya.
Sekarang ketika mendengar cerita saat
konseling aku tidak membuat dugaan,
namun mendengarkan saja. Kurasakan
sekarang (aku) menjadi lebih empati.
Dulu menduga-duga, ini kasusnya akan
begini, lalu begini”.
[“I don't think about the client much
now. Now I just let it flow, I don't avoid
cases that I predict will take a long time
to finish. Now when I hear stories during
counseling, I don't make assumptions, I
just listen. Now I feel more empathic. At
first, I was speculative, that this case
would be like this or that."]

Aside from avoiding certain cases, subject $\mathrm{L}$ can empathize due to active listening throughout the counseling process. Previously, subject L would be more preoccupied with making assumptions about the following stories from the victim's experience. 
The participants' statements in this study support Nibel's (2015) findings in a sample of 273 persons, whereby SUTT was found to reduce the prevalence of health complaints and medication, increase self-efficacy, confidence toward personal abilities, and optimism, which then enhanced quality of life.

Increases in body awareness after doing SUTT exercises corresponds to Thomesen \& Fougner's (2020) study. SUTT was concluded as a beneficial instrument to eliminate emotional tension and refine selfawareness toward the individual's self. In addition, the impact after the SUTT training also increases self-awareness of actions and thoughts, thus thereby enhancing focus and energy when doing activities (Thommessen $\&$ Fougner, 2020).

Another finding in this study is the initial past trauma release. Traumatic events cause the body to respond by contracting the psoas muscles and prepare for fight/flight/freeze responses (Mazon et al., 2018). Energy is produced and contained in the autonomous nervous system (Porges, 2012). Naturally occurring tremors release energy that is contained in the autonomous nervous system (Berceli, 2017) and releases the psoas (Herold, 2015), thus causing the ventral vagus nervous system to activate relaxes the subject when recalling past traumatic events.

The second benefit is a minimization of menstrual pain. This experience was reported by subject L, who was more comfortable during her cycle when prior cycles were quite painful, primarily in the past year (since working as a social worker). This condition corresponds to Koch's (2019) explanation on the psoas muscle, that menstrual pain itself causes stress that contracts the psoas. When the psoas muscles are protracted, it loosens and creates more space for the uterus, making it contract less and produces comfort during menstruation. In line with Tjaša's finding, SUTT exercises can give physical benefits as well as psychological benefits.
Physical benefits include increased flexibility, reduced workout soreness, pain relief (Tjaša, 2018).

The third benefit is improvements in digestive system functioning. This condition occurred in subject I and $\mathrm{L}$ after the first day of independent training, subject $\mathrm{I}$ and $\mathrm{L}$ experienced several natural defecations. According to subject I and L, they previously struggled with constipation. Tremors work from the body's center of gravity located in the pelvis, where the uterus and digestive system are located. When tremor responses are triggered in the body's gravitational center, it will resonate to the entire body and seek chronic tension that is severe in its path, then naturally shatter it (Berceli, 2017).

This study's limitation is notably in its methodology, that is, a one-group pretestposttest design. As this is a preliminary study, there is an open and wide opportunity for further research to apply a randomized controlled trial and further explore the effect of the intervention's duration toward STS symptom reduction. Another limitation is the lack of a control group toward extraneous variables such as exposure to client stories throughout the intervention process. Lastly, the collection of data to justify reductions in stress levels would be best supported by physiological parameters (i.e., heart rate, cortisol concentration), as the combination of the study's methodology and data source both contribute to the high possibility of bias in the results.

\section{CONCLUSION}

Based on the results and discussion on the effect of Self-induced Unclassified Therapeutic Tremor exercises toward secondary traumatic stress in social workers, it can be concluded that there exists an influence of Self-induced Therapeutic Tremors toward reductions in secondary traumatic stress in social workers. Selfinduced Therapeutic Tremor training was able to lower the average level of secondary 
traumatic stress in our samples of female social workers. Therefore, this study demonstrates that SUTT effectively reduces STS, although only to a minimal degree. Nonetheless, the research subjects are recommended to continue SUTT training independently according to their needs, i.e., 2-3 times per week administered routinely should they genuinely benefit from this training. Furthermore, for individuals who are professional social workers and deal with traumatic incidents, Self-induced Therapeutic Tremors may be used as a technique to reduce secondary traumatic stress symptoms.

\section{REFERENCES}

Annisa, R. (2018). Laporan pertanggungjawaban pelaksana harian tahun 2018. Laporan Pertanggungjawaban Pelaksana Harian. Yogyakarta: Rifka Annisa.

Ariapooran, S., \& Raziani, S. (2019). Sexual satisfaction, marital intimacy, and depression in married iranian nurses with and without symptoms of secondary traumatic stress. Psychological Reports, 122(3), 809-825.

American Psychiatric Association. (2013). Diagnostic and statistical manual of mental disorders (5th edition). Arlington, VA: American Psychiatric Publishing.

Baum, N. (2015). Secondary traumatization in mental health professionals: A Systematic review of gender findings. Trauma, Violence, \& Abuse, 1-15.

Baum, N., Rahav, G., \& Sharon, M. (2014, Mar). Heightened susceptibility to secondary traumatization: A metaanalysis of gender differences. (J. D. McLeigh, \& W. Spaulding, Eds.) American Journal of Orthopsychiatry, 84(2), 111-122.

Benuto, L. T., Yang, Y., Ahrendt, A., \& Cummings, C. (2018). The secondary traumatic stress scale: Confirmatory factor analyses with a national sample of victim advocates. Journal of Interpersonal Violence, 1-20.

Berceli, D. (2009). Evaluating the effects of stress reduction exercises employing mild tremors: A pilot study [Master's Thesis, Arizona State University]. Citeseer. http://citeseerx.ist.psu.edu/viewdoc/down load?doi=10.1.1.1043.9601\&rep=rep1\&t ype $=$ pdf

Berceli, D. (2010). Neurogenic tremors: A body-oriented treatment for trauma in large population. Trauma und Gewalt, 4(2), 148-156.

Berceli, D. (2017). Tension \& trauma releasing excercises. Jakarta, Indonesia: Sinotif Publishing.

Berceli, D., Salmon, M., Bonifas, R., \& Ndefo, N. (2014, September). Effects of self-induced unclassified therapeutic tremors on quality of life among nonprofessional caregivers: A Pilot Study. Global Advances In Health And Medicine, Volume 3(5), 45-48.

Bercier, M. L., \& Maynard, B. (2015). Interventions for secondary traumatic stress with mental health workers:A systematic review. Research on Social Work Practice, 25(1), 81-89.

Bolic, E. B. (2019). Secondary traumatic stress and vicarious traumatization in child welfare professionals in Serbia. Journal of Public Child Welfare, 13(2), 214-233.

Branson, D. C., Keller, J. E., \& Weigand, D. A. (2014). Vicarious trauma and decreased sexual desire: A hidden hazard of helping others. Psychological Trauma: Theory, Research, Practice, and Policy, 6(4), 398-403.

Bride, B. E., Robinson, M. M., Yegidis, B., \& Figley, C. R. (2004). Development and validation of the secondary traumatic 
stress scale. Research on Social Work Practice, 14(1), 27-35.

Brom, D., Stokar, Y., Lawi, C., Nuriel-Porat, V., Ziv, Y., Lerner, K., et al. (2017). Somatic experiencing for post-traumatic stress disorder:A randomized controlled outcome study. Journal of Traumatic Stress, 30, 304-312.

Butollo, W., Karl, R., König, J., \& Hagl, M. (2014). Dialogical Exposure in a GestaltBased Treatment for Posttraumatic Stress Disorder. Gestalt Review, 18(2), 112-129

Canfield, J. (2005). Secondary traumatization, burnout, and vicarious traumatization. Smith College Studies in Social Work, 75(2), 81-101.

Choi, G.-Y. (2011). Secondary traumatic stress of service providers who practice with survivors of family or sexual violence: A national survey of social workers. Smith College Studies in Social Work, 81, 101-119.

Ciftci, A., Jones, N., \& Corrigan, P. W. (2013). Mental health stigma in the muslim community. Journal of Muslim Mental Health, 7(1), 17-32.

Craig, C., \& Sprang, G. (2010). Compassion satisfaction, compassion fatigue, and burnout in a national sample of trauma treatmenttherapists. Anxiety, Stress, \& Coping, 23(3), 319-339.

Dana, D. A. (2018). The polyvagal theory in therapy: Engaging the rhythm of regulation (Norton series on interpersonal neurobiology). New York: W. W. Norton \& Company .

Descilo, T., Vedamurtachar, A., Gerbarg, P. L., Nagaraja, D., Gangadhar, B. N., Damodaran, B., et al. (2010, March 15). Effects of a yoga breath intervention alone and in combination with an exposure therapy for post-traumatic stress disorder and depression in survivors of the 2004 South-East Asia tsunami. Acta Psychiatrica Scandinavica, 121(4), 289300.

Dishman, R. K., Berthoud, H.-R., Booth, F. W., Cotman, C. W., \& Edgerton, V. R. (2012). Neurobiology of exercise. Obesity, 14(3), 345-356.

Fajar, A., \& Darwis, R. S. (2017). Tantangan kiprah pekerja sosial profesional di Indonesia. Riset \& Pkm, 4(1), pp. 1-140. Bandung: Universitas Padjajaran.

Figley, C. R. (2002). Compassion fatigue: Psychotherapists' chronic lack of self care. Journal of Clinical Psychology, 58(11), 1433-1441.

Figley, C. R. (Ed.). (2012). Encyclopedia of trauma an interdisciplinary guide. California: SAGE Publication, Inc.

Figley, C. R. (2013). Compassion fatigue: Coping with secondary traumatic stress disorder in those who treat the traumatized (eBook ed.). New York: Routledge.

Fisher, J. (2019). Sensorimotor psychotherapy in the treatment of trauma. Practice Innovations, 4(3), 156-165. https://doi.org/10.1037/pri0000096

Galek, K., Flannelly, K. J., Greene, P. B., \& Kudler, T. (2011). Burnout, secondary traumatic stress, and social support. Pastoral Psychology, 60(5), 633-649.

Gene-Cos, N., Fisher, J., Ogden, P., \& Cantrel, A. (2016). Sensorimotor psychotherapy group therapy in the treatment of complex PTSD. Annals of Psychiatry and Mental Health, 4(6): 1080.

Gibbons, S. B. (2011). Understanding empathy as a complex construct: A review of the literature. Clinical Social Work Journal, 39, 243-252. 
Gil, S., \& Weinberg, M. (2015). Secondary trauma among social workers treating trauma clients:The role of coping strategies and internal resources. International Social Work, 58(4), 551561.

Glück, T., Tran, U., Raninger, S., \& LuegerSchuste, B. (2016). The influence of sense of coherence and mindfulness on PTSD symptoms and post-traumatic cognitions in a sample of elderly Austrian survivors of World War II. International Psychogeriatrics, 28(3), 435 - 441. doi:10.1017/S104161021500143X

Greinacher, A., Derezza-Greeven, C., Herzog, W., \& Nikendei, C. (2019). Secondary traumatization in first responders: A systematic review. European Journal of Psychotraumatology, 10(1), 1-21.

Halida, N., Ikhtiarini, E. D., \& Rasni, H. (2016). Pengalaman keluarga dalam pemenuhan kebutuhan perawatan diri pada orang dengan gangguan jiwa (ODGJ) dengan pasung di Kecamatan Ambulu Kabupaten Jember. e-Jurnal Pustaka Kesehatan, 4 (1), 78-85.

Hannah, B., \& Woolgar, M. (2018). Secondary trauma and compassion fatigue in foster carers. Clinical Child Psychology and Psychiatry, 23(4), 629643.

Hardy, C., Griffiths, A., Thorne, E. and Hunter, M. (2019), "Tackling the taboo: talking menopause-related problems at work". International Journal of Workplace Health Management, 12(1), 28-38. doi.org/10.1108/IJWHM-03-20180035 .

Harrison, E. G., Keating, J. L., ManipPT, G., \& Morgan, P. (2018). Novel exercises for restless legs syndrome: A randomized, controlled trial. J Am Board Fam Med, 31(5), 783-794. 10.3122/jabfm.2018.05.180065
Heath, R., \& Beattie, J. (2019, July). Case report of a former soldier of using TRE (Tension \& Trauma Releasing Excercise) for post-traumatic stress disorder selfcare. Journal of Military and Veterans' Health, 27(3), 35-40.

Hensel, J. M., Ruiz, C., Finney, C., \& Dewa, C. S. (2015). Meta-analysis of risk factors for secondary traumatic stress in therapeutic work with trauma victims. Journal of Traumatic Stress, 2, 83-91.

Herold, A. (2015). Neurogenic tremor through TRE (tension, stress and trauma releasing exercises) according to $\mathrm{D}$. Berceli in the treatment of post-traumatic

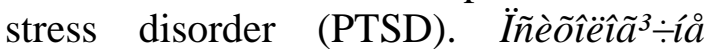

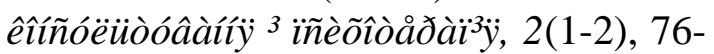
84.

Hildebrand, A., Grand, D., \& Stemmler, M. (2017). Brainspotting - the efficacy of a new therapy approach for the treatment of post-traumatic stress disorder in comparison to eye movement desensitization and reprocessing. Mediterranean Journal of Clinical Psychology, 5(1), 1-17.

Jackson, S. L. (2015). Research methods and statistics: A critical thinking approach (5th ed.). Boston, USA: Cengage Learning.

Jenkins, S., Mitchell, J., Baird, S., Whitfield, S., \& Meyer, H. (2010). The counselor's trauma as counseling motivation: Vulnerability or stress inoculation? Journal Interpers Violence, 26, 23922412.

Johansen, A. B., Kristiansen, E., Bjelland, I., \& Tavakoli, S. (2019). Secondary traumatic stress in Norwegian SUD therapists: Symptoms and related factors. Nordic Studies on Alcohol and Drugs, 110.

Kementerian Ketenagakerjaan \& Badan Pusat Statistik [BPS]. (2014). Klasifikasi 
baku jenis pekerjaan indonesia [KBJI].Jakarta: Badan Pusat Statistik.

Klarer, M., Arnold, M., Günther, L., Winter, C., Langhans, W., \& Meyer, U. (2014). Gut vagal afferents differentially modulate innate anxiety and learned fear. Journal of Neuroscience, 34(21), 70677076.

Koch, L. (2019). Stalking wild psoas: Embodying your core intelligence. Berkeley, California: North Atlantic Books.

Kolk, B. A., Stone, L., West, J., Rhodes, A., Emerson, D., Suvak, M., et al. (2014). Yoga as an adjunctive treatment for posttraumatic stress disorder: A randomized controlled trial. Journal of Clinical Psychiatry, 75, e1-e7.

Kulkarni, S., Bell, H., Hartman, J. L., \& Herman-Smith, R. L. (2013, June 3). Exploring individual and organizational factors contributing to compassion satisfaction, secondary traumatic stress, and burnout in domestic violence service providers. Journal of the Society for Social Work and Research, 4(2), 114130.

Kumar, A., Bhat, P., \& Sumalatha Ryali, R. (2018). Study of quality of life among health workers and psychosocial factors influencing it. Industrial Psychiatry Journal, 27(1), 96-102.

Landis, Ellen M. (2010). Sharevision: A collarative-reflective, expressive arts intervention to address trauma. Expressive Therapies Dissertations. 75. Retrieved from https://digitalcommons.lesley.edu/express ive_dissertations/75

Landis-Shack, N., Heinz, A., \& Bonn-Miller, M. (2017). Music therapy for posttraumatic stress in adults: A theoretical review. Psychomusicology, 27(4), 334342
Lee, R. (2017). The impact of engaging with clients 'trauma stories: Personal and organizational strategies to manage probation practitioners' risk of developing vicarious traumatization. The Journal of Community and Criminal Justice, 64(4), 372-387.

Leitch, M., Vanslyke, J., \& Allen, M. (2009). Somatic experiencing treatment with social service workers following hurricanes Katrina and Rita. Social Work, 54(1), 9-18.

Levenson, R. W. (2014, April). The autonomic nervous system and emotion. Emotion Review, 6(2).

Loprinzi, P., Pazirei, S., Robinson, G., Dickerson, B., Edwards, M., \& Rhodes, R. (2020). Evaluation of a cognitive affective model of physical activity behavior. Health Promot Perspect, 10(1), 88-93.

Ludick, M., \& Figley, C. R. (2017). Toward a mechanism for secondary trauma induction. Traumatology, 23(1), 112123.

Lynning, M., Svaneb, C., Wetergaarda, K., Bergien, S. O., Gunnersen, S. R., \& Skovgaard, L. (2021). Tension and trauma releasing exercises for people with multiple sclerosise: An exploratory pilot study. Journal of Traditional and Complementary Medicine, 1-7.

Maack, C. (2013). Comparing treatment outcome of guided imagery and music and psychodynamic imaginative trauma therapy for women with complex PTSD. 28th Annual Conference: Integrating Science and Practice: Moving forward together in the field of trauma and dissociation. Long Beach, United States.

MacRitchie, V., \& Leibowitz, S. (2010). Secondary Traumatic Stress, level of exposure, empathy and social support in 
trauma workers. South African Journal of Psychology, 40(2), 149-158.

Mazon, S., Oskay, O., Comer, S. D., \& Durlu, E. (2018). Care views from complementary and alternative medicine including Brennan Healing Science ${ }^{\circledR}$ for self-care of medical professionals and laypersons in Turkey: A workshop evaluation. Journal of Alternative Medicine Research, 10(3), 253-262.

McCann, I. L., \& Pearlman, L. A. (1990). Vicarious traumatization: A framework for understanding the psychological effects of working with victims. Journal of Traumatic Stress, 3(1), 131-149.

McFarlane, A. C. (2010). The long-term costs of traumatic stress: intertwined physical and psychological consequences. World Psychiatry, 9, 3-10.

Nibel, H. (2015). Shake it up baby! Trauma and tension releasing exercises $\left(\mathrm{TRE}^{\circledR}\right.$ ) as a new promising offering in promoting occupational health. The Gesellschaft für Arbeitswissenschaft Spring Convention (pp. 1-16). Karlruhe, Germany: Society of Occupational Science.

Novoa, M. P., \& Cain, D. (2014). The effects of Reiki treatment on mental health professionals who are at risk for secondary traumatic stress: A placebo control study. Best Practices in Mental Health, 10(1), 29-46.

Pearlman, L. A., \& Mac Ian, P. (1995). Vicarious traumatization: An empirical study of the effects of trauma work on trauma therapists. Professional Psychology: Research and Practice, 26, 558-565.

Porges, S. W. (2012, November). The polyvagal theory: Neurophysiological foundations of emotions, attachment, communication, self-regulation. Journal of the Canadian Academy of Child and Adolescent Psychiatry, 21(4), 313-314.
Price, C.J. and Hooven, C. (2018). Interoceptive awareness skills for emotion regulation: Theory and approach of mindful awareness in Body-Oriented Therapy (MABT). Frontiers in Psychology, 9:798, 1-2. doi: 10.3389/fpsyg.2018.00798.

Price, M., Spinazzola, J., Musicaro, R., Turner, J., Suvak, M., Emerson, D., et al. (2017). Effectiveness of an extended yoga treatment for women with chronic post-traumatic stress disorder. The Journal of Alternative and Complementary Medicine, 23(4).

Priebe, S., Omer, S., Giacco, D., \& Slade, M. (2014). Resource-oriented therapeutic models in psychiatry: conceptual review. The British Journal of Psychiatry, 204, 256-261. doi: 10.1192/bjp.bp.113.135038.

Quinn, A., Ji, P., \& Nackerud, L. (2019). Predictors of secondary traumatic stress among social workers:Supervision, income, and caseload size. Journal of Social Work, 19(4), 504-528.

Radey, M., \& Figley, C. (2007). The social psychology of compassion. Clinical Social Work Journal, 35, 207-214.

Ramadhan, M. D. (2016). Hubungan profesional quality of life dengan secondary traumatic stress pada petugas polisi unit perlindungan perempuan dan anak di Polda Metro Jaya dan jajarannya. Tesis. Jakarta: Universitas Mercu Buana Jakarta.

Ray, S. L., Wong, C., White, D., \& Heaslip, K. (2013). Compassion satisfaction, compassion fatigue, work life conditions, and burnout among frontline mental health care professionals. Traumatology, 19, 255-267.

Reffi, A., Pinciotti, C., Darnell, B., \& Orcutt, H. (2019). Trait mindfulness and PTSD symptom clusters: Considering the 
influence of emotion dysregulation. Personality and Individual Differences, $137,62-70$.

Robinson-Keilig, R. A. (2014). Secondary traumatic stress and disruptions to interpersonal functioning among mental health therapists. Journal of Interpersonal Violence, 29(8), 14771496.

Senior, J. (2017, September). Book review: The Body Bears the Burden: Trauma, Dissociation, and Disease. SAGE Journal, 3(3), 310-312.

Senter, A., Morgan, R. D., Serna-McDonald, C., \& Bewley, M. (2010). Correctional psychologist burnout, job satisfaction and life satisfaction. Psychological Services, 7, 190-201.

Showalter, S. E. (2010). Compassion fatigue: What is it? Why does it matter? Recognizing the symptoms, acknowledging the impact, developing the compassion fatigue: What is it? Why acknowledging theimpact, developing the tools to prevent compassion fatigue, and strengthen the pr. American Journal of Hospice and Palliative Medicine, 27(4), 239-242.

Spinazzola, J., Rhodes, A. M., Emerson, D., Earle, E., \& Monroe, K. (2011, August 25). Application of Yoga in Residential Treatment of Traumatized Youth. Journal of the American Psychiatric Nurses Association, 17(6), 431-444.

Suparti, S., Rosa, E. M., \& Permatasari, Y. I. (2014). Action research: Pelaporan insiden keselamatan pasien di IBS RSUP Dr. Soeradji Tirtonegoro Klaten. Muhammadiyah Journal of Nursing, 185198.
Thommessen, C. S., \& Fougner, M. (2020). Body awareness in acting - a case study of TRE as a supporting tool for drama students' personaland professional development. Theatre, Dance and Performance Training, 11(4), 434-452.

Tjaša, S. P. (2018). TRE for athletes. 5th International Scientific Conference of Slovenian Gymnastics Federation (pp. 151-159). Ljubljana: Slovenian Gymnastics Federation.

Valiente-Gómez, A., Moreno-Alcázar, A., Treen, D., Cedrón, C., Colom, F., Pérez, V., et al. (2017). EMDR beyond PTSD: A systematic literature review. Frontiers in Psychology, 8:1668, 1-10.

Wagaman, M. A., Geiger, J. M., Shockley, C., \& Segal, E. A. (2015, July). The role of empathy in burnout, compassion satisfaction, and secondary traumatic stress among social workers. Journal Social Work, 60(3), 201-209.

West, J., Liang, B., \& Spinazzola, J. (2017). Trauma sensitive yoga as a complementary treatment for posttraumatic stress disorder: A qualitative descriptive analysis. International Journal of Stress Management, 24(2), 173-195.

Wilkinson, M. (2003). The brain and the inner world: An introduction to the neuroscience of subjective experience. Journal of Analytical Psychology, 48(2), 274-275.

Zaki, J., \& Ochsner, K. (2012, May). The neuroscience of empathy: progress, pitfalls and promise. Nature Neuroscience, 15(5), 675-680 